\title{
PENGARUH PEMBERIAN EKSTRAK BAWANG PUTIH (Allium sativum L.) DAN LAMA PENYIMPANAN TERHADAP DAYA AWET TAHU PUTIH
}

\author{
Hendra \\ Dosen Pendidikan Biologi Fakultas Keguruan dan Ilmu Pendidikan UM Palembang \\ Jl. Jend. A. Yani 13 Ulu Palembang \\ email: hendrafkipump@gmail.com
}

\begin{abstract}
Tofu includes onthe comestible that is easy to be perished then it can be called as high perishable food. Tofu has much protein and water that becomes a good media tothe growth of microbes. Garlic (Allium sativum L) is also antimicrobial E.coli, Shigellasonnei, Staphylococcus sureus and Aerobacteraerogenes, Staphylococcus sureus and Aerobacteraerogenes. The other usages are to reduce the number of aerobic bacteria, coliform and other microorganisms so the comestible that was added garlic could be preserved. The problem of this study was whether or not the garlic extract gave an influence on the long of white tofu to be saved. The objective of this study was to find out the influence of garlic extract (Allium sativum L.) on the lasting of tofu. The hypothesis of this study was there was an influence of the given concentration of garlic extract (Allium sativum $L$ ) on the lasting of tofu. This study used experimental method with completed randomized design (RAL) that consisted on six treatments and four examinations. The variant analysis found that on Table 1 significant level $\mathrm{F}_{\text {obtained }}$ treatment $>\mathrm{F}_{\text {table }}$ and $\mathrm{F}_{\text {table }}$ was $0.05 \mathrm{~F}_{\text {table }} 0.01$ was $2.93<43.306>4.58$ means that the garlic extract given gave a significant influence on the lasting of tofu. From the average of microorganisms in the tofu, it could be concluded that the concentration of treatment P1 (80gr garlic extract (Allium sativum L) with the keeping time 1x24 hours gave significant influence on the lasting of tofu.
\end{abstract}

Keywords: Extract of garlic; Allium sativum L; Lasting power; White tofu.

\section{PENDAHULUAN}

Tahu termasuk bahan pangan yang cepat mengalami kerusakan sehingga dapat digolongkan ke dalam golongan high perishable food. Komposisi tahu yang banyak mengandung protein dan air menyebabkan tahu merupakan media yang cocok untuk tumbuhnya mikroba sehingga tahu menjadi cepat mengalami kerusakan. Tahu hanya dapat tahan selama kurang lebih tiga hari tanpa menggunakan bahan pengawet walaupun disimpan pada suhu rendah, yaitu suhu maksimum $15^{\circ} \mathrm{C}$.Komposisi suatu bahan pangan sangat menentukan jenis mikroorganisme yang dapat tumbuh dengan baik pada bahan tersebut. Mikroorganisme penyebab kerusakan pada bahan pangan berkadar air tinggi dengan $\mathrm{pH}$ netral terutama berasal dari golongan bakteri (Shurtleff \& Aoyagi 1979) dalam Mariana (2010).

Sejak akhir tahun 1970 sampai sekarang ramai lagi, beberapa produsen dan pedagang tahu di kotakota besar diduga mengawetkan tahunya dengan formalin. Formalin bukan merupakan zat pengawet untuk makanan, tetapi disalahgunakan untuk pengawetan industri makanan, hal ini sering ditemukan dalam industri rumahan karena mereka tidak terdaftar dan tidak terpantau oleh Departemen Kesehatan dan Badan POM setempat. Produsen sering menggunakan formalin sebagai bahan pengawet makanan tidaklah tepat karena bisa menimbulkan berbagai gangguan kesehatan bagi konsumen yang memakannya. Menurut MFL (2004), 5-30 ppm formaldehida menyebabkan kerusakan kronis paru-paru dan pada konsentrasi diatas 100 ppm dapat menyebabkan kematian (Koswara, 2011).

Dalam usaha untuk mencari bahan pengawet yang tidak berbahaya dan tentunya aman bila digunakan, peneliti pun mencoba mengkaji tentang manfaat bawang putih (Allium sativum L) untuk dijadikan sebagai bahan pengawet alami.

Bawang putih (Allium sativum L) merupakan umbi dari tanaman Allium sativum L., termasuk dalam famili Amarylidaceae, manfaat lainnya sebagai bumbu masakan daging yang dikalengkan, saus, sup, dan lainnya. Bawang putih mengandung minyak volatil kurang lebih $0.2 \%$ yang terdiri dari $60 \%$ dialil disulfit, $20 \%$ dialil trisulfit, $6 \%$ alil propil disulfit, dan sejumlah kecil dietil disulfit, 
dialil polysulfit, allinin, dan allisin. Minyak ini berwarna kuning kecoklatan dan berbau pedas. Bau bawang putih yang sebenarnya diperkirakan berasal dari dialil disulfit (Farrell 1985) dalam Mariana (2010).

Bawang putih (Allium sativum $\mathrm{L}$ ) juga bersifat antimikroba E.coli, Shigella sonnei, Staphylococcus aureus dan Aerobacter aerogenes. Manfaat lainya adalah dapat mengurangi jumlah bakteri aerob, E.coli dan mikroorganisme lainnya sehingga bahan makanan yang ditambahkan bawang putih akan lebih awet (Sutomo\& Budi, 2012)

Menurut Soeid (2012) bawang putih (Allium sativum $\mathrm{L}$ ) dapat digunakan dalam mengawetkan beberapa makanan, antara lain tahu putih dan kuning, mie basah dan ikan segar, dengan mengambil beberapa siung bawang putih, kemudian digerus. Setelah lembut, kemudian diberi air dan disaring, air dari bawang putih ini kemudian dituangkan ke dalam air yang dibuat untuk merendam tahu. Bawang putih Allium sativum L ) yang mengandung anstiseptik itu mampu menjadikan tahu bertahan hingga dua hari.

Dari hasil penelitian terdahulu dalam mengawetkan tahu putih yaitu dengan mencampur bahan rempah yaitu, kunyit, kayu manis, bawang putih, dan biji pala. Kemudian keempat jenis pengawet alami tersebut dihaluskan dan dicampurkan pada tahu putih, tetapi hanya mempunyai efek yang tidak jauh berbeda antara setiap perlakuan, yaitu hanya dapat mengawetkan tahu selama dua hari penyimpanan (pada suhu ruang) (Mariana, 2010).

Berdasarkan uraian di atas maka peneliti tertarik untuk mengadakan penelitian untuk mengawetkan tahu dengan menggunakan bawang putih yang diambil estraknya sebanyak 80 gram. Peneliti berusaha untuk mengukur efektivitas ekstrak bawang putih dalam mengukur daya awet tahu.

\section{METODE PENELITIAN}

Penelitian ini dilaksanakan pada tanggal 17 Juni sampai dengan 28 Juni 2016 di Laboratorium Biologi FKIP Universitas Muhammadiyah Palembang. Adapun alat-alat yang digunakan dalam penelitian ini adalah sebagai berikut : blender, pisau, plastik polyetilen, corong pemisah, penyaring, panci, kompor,cawan petri, tabung reaksi, pinset, Bunsen, autoklafe, incubator, penggaris, kertas label serta peralatan lainnya adalah $\mathrm{pH}$ meter dan peralatan untuk pengamatan evaluasi, uji organoleptik serta pada pengamatan visual kerusakan tahu menggunakan piring dan sendok. Bahan-bahan yang dipergunakan dalam penelitian ini adalah: kacang kedelai yang digunakan adalah kacang kedelai putih 400 gr, Air $(100 \mathrm{ml})$, perasan air jeruk nipis sebagai anti mikroba, cuka sebagai bahan untuk mengentalkan, dan ekstrak bawang putih (Allium sativum L.) sebanyak 80 gram, media agar NA, kertas HVS, spiritus, tissue, alkohol $70 \%$, kapas lidi steril. Penelitian ini merupakan penelitian eksperimen dengan menggunakan pola Rancangan Acak Lengkap (RAL) dengan dari 6 perlakuan dan 4 kali pengulangan dengan menggunakan $80 \mathrm{gr} / 100 \mathrm{ml}$ ekstrak bawang putih (Allium sativum L.).

Prosedur kerja pada penelitian ini yaitu dimulai dengan pembuatan ekstrak bawang putih(Allium sativum L.). Bawang putih ini diperoleh dari pasar tradisional.Pembuatan ekstrak bawang putih (Allium sativum L.) dilakukan dengan cara memilih bawang putih yang masih segar dan berwarna kekuningan, kemudian dicuci bersih dan dianginanginkan, kemudian ditimbang, kemudian dihaluskan menggunakan blender. Hasil dari bawang putih yang telah dihaluskan, dimaserasi selama 3x24 jam menggunakan etanol 96\%, kemudian disaring dengan kertas saring. Hasil filtrasi diuapkan dengan Rotary Vacum Evaporator. Ekstrak ditempatkan dalam botol steril dan ditutup dengan alumunium foil.

Setelah pembuatan ekstrak bawang putih(Allium sativum L.) selesai maka dilakaukan persiapan proses pembuatan tahu putih, dimana kacang kedelai blender dengan air, perbandingannya $4: 1$. setelah halus tuang ke dalam panci dan masak hingga cukup mendidih, kemudian campurkan air cuka/perasan jeruk nipis sebagai larutan pengental, setelah tahu putih sedikit mengental pisahkan menjadi empat bagian dimana nantinya akan diberikan perlakuan berbeda, kemudian campurkan masing-masing konsentrasi $\left(\mathrm{P}_{0}, \mathrm{P}_{1}, \mathrm{P}_{2}, \mathrm{P}_{3}, \mathrm{P}_{4},\right)$ ke dalam 24 wadah tahu yang baru mulai akan mengental, kemudian dimasukkan ekstrak bawang putih(Allium sativum L.), setelah dicampur aduk hingga tercampur larutan ekstrak bawang putih(Allium sativum L.) tersebut, setelah mulai mengental dinginkan terlebih dahulu baru kemudian di press dan di cetak, kemudian tuang 1 ml larutan tahu kedalam media NA.

Data hasil penelitian ini dianalisis dengan pendekatan statistik menggunakan analisis keragaman. Data yang diperoleh dianalisa dengan menggunakan analisis keragaman rancangan acak lengkap (RAL) untuk menentukan apakah ada perbedaan antara perlakuan dengan membandingkan $\mathrm{F}$ hitung lebih besar dari $\mathrm{F}$ table pada taraf uji $1 \%$ maka dikatakan berpengaruh sangat nyatadan bila $\mathrm{F}$ hitung lebih kecil dari $\mathrm{F}$ 
table pada taraf uji 5\% maka dapat dikatakan tidak berbeda nyata.

\section{HASIL DAN PEMBAHASAN}

A. Hasil
Berdasarkan hasil penelitian terhadap pengaruh lama penyimpanan terhadap daya awet tahu putih yang diberi ekstrak bawang putih (Allium sativum. L.) diperoleh data uji mikroorganisme dan uji organoleptik, dapat dilihat pada tabel berikut:

Tabel 1. Rata-rata Pertumbuhan Mikroorganisme pada Tahu Putih yang telah di Inokulasi.

\begin{tabular}{cc}
\hline Perlakuan & Nilai rata-rata jumlah mikroorganisme \\
\hline $\mathrm{P}_{0}$ & 286,5 \\
$\mathrm{P}_{1}$ & 100,15 \\
$\mathrm{P}_{2}$ & 119,05 \\
$\mathrm{P}_{3}$ & 131,45 \\
$\mathrm{P}_{4}$ & 166,85 \\
$\mathrm{P}_{5}$ & 209,15 \\
\hline
\end{tabular}

Pada Tabel 1. dari hasil nilai rata-rata jumlah mikroorganisme menunjukkan jumlah mikroorganisme terbanyak terdapat pada perlakuan $\mathrm{P}_{0}$ dimana $\mathrm{P}_{0}$ merupakan kontrol (tanpa pemberian ekstrak bawang putih) dan pada Tabel 1 juga menunjukkan semakin lama penyimpanan maka jumlah mikroorganisme akan semakin bertambah, untuk melihat lebih jelasnya disajikan dalam bentuk grafik pada Gambar 1.

Berikut adalah jumlah rata-rata pertumbuhan mikroorganisme pada tahu putih yang disajikan dalam bentuk grafik.

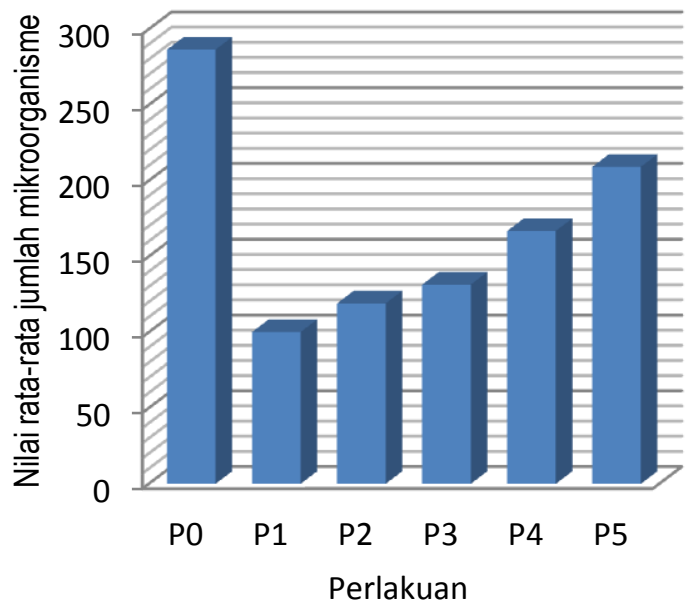

Keterangan:

$\mathrm{P}_{0}=$ Kontrol (tanpa pemberian ekstrak bawang putih)

$\mathrm{P}_{1}=1 \times 24$ jam (80 gram bawang putih)

$\mathrm{P}_{2}=2 \times 24$ jam (80 gram bawang putih)

$\mathrm{P}_{3}=3 \times 24$ jam (80 gram bawang putih)

$\mathrm{P}_{4}=4 \times 24$ jam (80 gram bawang putih)

$\mathrm{P}_{5}=5 \times 24$ jam (80 gram bawang putih)

\section{Gambar 1 Data Hasil Pengaruh Lama Penyimpanan terhadap Daya Awet Tahu Putih setelah pemberian Ekstrak Bawang Putih (Allium sativum L.)}

\section{Uji Organoleptik}

Bahan makanan akan diujicobakan kepada 20 orang panelis. Masing-masing panelis akan memberikan nilai cita rasa bahan tersebut jumlah nilai dari panelis akan memberikan akan menentukan mutu atau penerimaan terhadap bahan yang diuji. Berdasarkan hasil penelitian dari 20 orang panelis diperoleh nilai rata-rata tingkat kesukaan terhadap aroma, tekstur, dan warna pada tahu putih dapat dilihat pada Tabel 2 .

Tabel 2. Nilai Rata-rata Tingkat Kesukaan pada Tahu Putih

\begin{tabular}{cccc}
\hline \multirow{2}{*}{ Perlakuan } & \multicolumn{3}{c}{ Nilai Rata-rata Uji Organoleptik } \\
\cline { 2 - 4 } & Aroma & Warna & Tekstur \\
\hline $\mathrm{P}_{0}$ & 2,125 & 1,5125 & 1,375 \\
$\mathrm{P}_{1}$ & 2,4625 & 3,0875 & 1,5875 \\
$\mathrm{P}_{2}$ & 2,4125 & 2,6625 & 1,625 \\
$\mathrm{P}_{3}$ & 2,5 & 3,0375 & 1,525 \\
$\mathrm{P}_{4}$ & 2,475 & 2,3 & 2,24583 \\
$\mathrm{P}_{5}$ & 2,5125 & 2,5875 & 1,6625 \\
\hline
\end{tabular}

Nilai rata-rata tertinggi kesukaan panelis terhadap aroma tahu putih pada perlakuan $\mathrm{P}_{3}$ dan $\mathrm{P}_{5}$ dengan nilai 2,5 dan 2,5125 dengan kriteria disukai, warna tahu putih menunjukkan nilai rata-rata tertinggi pada perlakuan $\mathrm{P}_{1}$ dan $\mathrm{P}_{3}$ dengan nilai 3,0875 dan 3,0375 dengan kriteria disukai, dan 
tekstur tahu putih menunjukkan nilai rata-rata tertinggi perlakuan $\mathrm{P}_{4}$ dan $\mathrm{P}_{5}$ dengan nilai 2,24583 dan 1,6625 dengan kriteria disukai.

Dari hasil yang diperoleh pada Tabel 1 dan Tabel 2 kemudian dilakukan analisis sidik ragam dengan pola RAL dengan 6 perlakuan dan 4 kali ulangan. Adapun hasil analisis tersebut adalah sebagi berikut:

Tabel 3. Analisis Sidik Ragam Pengaruh Lama Penyimpanan terhadapDayaAwet Tahu Putih yang Diberi Ekstrak Bawang Putih (Alliumsativum L.)

\begin{tabular}{|c|c|c|c|c|c|c|}
\hline \multirow{2}{*}{ SK } & \multirow{2}{*}{ DB } & \multirow{2}{*}{ JK } & \multirow{2}{*}{ KT } & \multirow{2}{*}{ F. Hitung } & \multicolumn{2}{|c|}{ F. Tabel } \\
\hline & & & & & 0,05 & $\mathbf{0 , 0 1}$ \\
\hline Perlakuan & 5 & 481362,04 & 96272,40 & $298,61 * *$ & 2,30 & 3,20 \\
\hline Galat & 114 & 36754,55 & 322,408 & & & \\
\hline Total & 119 & 518116,59 & & & & \\
\hline
\end{tabular}

Keterangan : $* *=$ Berpengaruh sangat nyata

Berdasarkan analisis data diketahui bahwa $F_{\text {hitung }}>F_{\text {tabel }}$, hal ini menyatakan bahwa ekstrak bawang putih (Allium sativum L.) memberikan pengaruh sangat nyata terhadap lama penyimpanan terhadap daya awet tahu putih. Dari analisis sidik ragam pengaruh konsentrasi ekstrak Bawang Putih (Allium sativum L.) terhadap daya simpan tahu putih. Pada Tabel 4.6 diketahui bahwa $\mathrm{F}$ hitung lebih besar dari $F$ tabel 0,05 dan $F$ tabel 0,01 yaitu 2,93
$<43,306>$ 4,58. Hal ini berarti perlakuan memberikan pengaruh sangat nyata terhadap jumlah mikroorganisme, karena adanya perbedaan pada setiap perlakuan. Selanjutnya untuk mengetahui perbedaan pengaruh dari masing-masing perlakuan dilakukan uji lanjut dengan menggunakan uji Beda Nyata Jujur (BNJ) pada taraf 0,05 dan 0,01 \% seperti pada Tabel 4 berikut:

Tabel 4. Hasil Uji Beda Nyata Jujur (BNJ) Pengaruh Lama Penyimpanan Terhadap DayaAwet Tahu Putih yang Diberi Ekstrak Bawang Putih (Allium sativum L.)

\begin{tabular}{|c|c|c|c|c|c|c|c|}
\hline \multirow{2}{*}{ Perlakuan } & \multirow{2}{*}{$\begin{array}{l}\text { Nilai rata-rata jumlah } \\
\text { mikroorganisme }\end{array}$} & \multicolumn{6}{|c|}{ Perlakuan } \\
\hline & & $\mathbf{P}_{5}$ & $\mathbf{P}_{4}$ & $\mathbf{P}_{\mathbf{3}}$ & $\mathbf{P}_{2}$ & $\mathbf{P}_{1}$ & $\mathbf{P}_{\mathbf{0}}$ \\
\hline $\mathrm{P}_{0}$ & 286,5 & $77,35 * *$ & $119,65 * *$ & $155,05 * *$ & $167,45^{* *}$ & $186,35 * *$ & - \\
\hline $\mathrm{P}_{1}$ & 100,15 & $109 * *$ & $66,7 * *$ & $31,3 * *$ & $18,9 *$ & - & - \\
\hline $\mathrm{P}_{2}$ & 119,05 & $90,1 * *$ & $47,8 * *$ & $12,4^{\mathrm{ns}}$ & - & - & - \\
\hline $\mathrm{P}_{3}$ & 131,45 & $77,7 * *$ & $35,4 * *$ & - & - & - & - \\
\hline $\mathrm{P}_{4}$ & 166,85 & $42,3 * *$ & - & - & - & - & - \\
\hline \multirow[t]{2}{*}{$\mathrm{P}_{5}$} & 209,15 & - & - & - & - & - & - \\
\hline & & \multicolumn{3}{|c|}{ BNJ $0,05=16,46$} & \multicolumn{3}{|c|}{ BNJ $0,01=19,55$} \\
\hline
\end{tabular}

\footnotetext{
Keterangan:

$* *=$ Berbeda Sangat Nyata

$*=$ Berbeda Nyata

Ns $=$ Tidak Berbeda Nyata
}

Berdasarkan hasil uji Beda Nyata Jujur (BNJ) pada Tabel 4 diatas menunjukkan $\mathrm{P}_{1}$ berbeda sangat nyata dengan $\mathrm{P}_{3}, \mathrm{P}_{4}, \mathrm{P}_{5}$, akan tetapi $\mathrm{P}_{1}$ berbeda nyata dengan $\mathrm{P}_{2}$. $\mathrm{P}_{2}$ berbeda sangat nyata dengan
$\mathrm{P}_{4}$, dan $\mathrm{P}_{5}$, akan tetapi $\mathrm{P}_{2}$ tidak berbeda nyata dengan $\mathrm{P}_{3} . \mathrm{P}_{3}$ berbeda sangat nyata dengan $\mathrm{P}_{4}$ dan $\mathrm{P}_{5}$. Dan $\mathrm{P}_{4}$ berbeda sangat nyata dengan $\mathrm{P}_{5}$.

Tabel 5. Analisis Uji Organoleptik Terhadap Aroma, Warna, dan Tekstur Tahu Putih.

\begin{tabular}{cccc}
\hline Parameter & Nilai Kritik $(\mathbf{T})$ & F Tabel & Keterangan \\
\hline Aroma & 454,98 & 2,50 & Ada Perbedaan \\
Warna & 24,85 & 2,50 & Pengaruh dari \\
Tekstur & 935,76 & 2,50 & Perlakuan yang diuji \\
\hline
\end{tabular}

Hasil analisis uji organoleptik terhadap aroma, warna, dan tekstur tahu putih dapat dilihat pada Tabel 5 menunjukkan bahwa $\mathrm{T}$ kritik dan $\mathrm{F}$ tabel berpengaruh sangat nyata.

\section{B. Pembahasan}

Berdasarkan hasil analisis sidik ragam pengaruh konsentrasi ekstrak Bawang Putih (Allium sativum L.) terhadap daya simpan tahu putih. Pada Tabel 3 diketahui bahwa $\mathrm{F}_{\text {hitung }}$ lebih besar dari $\mathrm{F}$ 
tabel 0,05 dan $\mathrm{F}_{\text {tabel }} 0,01$ yaitu $2,93<43,306>4,58$. Hal ini berarti perlakuan memberikan pengaruh sangat nyata terhadap jumlah mikroorganisme, karena adanya perbedaan pada setiap perlakuan.

Berdasarkan hasil uji BNJ pada Tabel 4 menunjukkan bahwa hasil uji beda nyata jujur pengaruh konsentrasi Ekstrak Bawang Putih (Allium sativum L.) terhadap masa simpan tahu putih, menunjukkan perlakuan $\mathrm{P}_{0}$ berbeda sangat nyata dengan $\mathrm{P}_{1}, \mathrm{P}_{2}, \mathrm{P}_{3}, \mathrm{P}_{4}, \mathrm{P}_{5} . \mathrm{P}_{1}$ berbeda sangat nyata dengan $\mathrm{P}_{4}, \mathrm{P}_{5}$, tetapi berbeda nyata dengan $\mathrm{P}_{2}$, dan $\mathrm{P}_{3} . \mathrm{P}_{2}$ berbeda sangat nyata dengan $\mathrm{P}_{4}, \mathrm{P}_{5}$, tetapi tidak berbeda nyata dengan $\mathrm{P}_{3} . \mathrm{P}_{3}$ berbeda sangat nyata dengan $\mathrm{P}_{4}$, tetapi berbeda nyata dengan $\mathrm{P}_{5}$. Dan $\mathrm{P}_{4}$ berbeda sangat nyata dengan $\mathrm{P}_{5}$. Semakin lama masa simpan maka akan semakin banyak mikroorganisme pembusuk, hal ini dikarenakan komposisi dari tahu putih yang banyak mengandung protein dan air.

Pada Gambar 1 dilihat dari nilai rata-rata jumlah mikroorganisme pada tahu putih terlihat bahwa pada perlakuan kontrol menunjukkan grafik pertumbuhan yang tinggi hal ini dipengaruhi oleh tanpa adanya pemberian ekstrak bawang putih, selain itu kontaminasi lingkungan serta waktu yang cukup lama sebelum tahu putih di uji mikroorganisme di laboratorium juga mempengaruhi tingginya jumlah pertumbuhan mikroorganisme pada perlakuan kontrol.

Menurut Koswara (2011) penyebab tahu mudah rusak adalah kadar air dan protein tahu tinggi, masing-masing 86 persen dan $8-12$ persen. Disamping kandungan lemak 4,8 persen dan karbohidrat 1,6 persen. Kondisi ini mudah mengundang tumbuhnya jasad renik pembusuk, terutama bakteri. Karena adanya kandungan Ekstrak Bawang Putih (Allium sativum L.) yang telah dicampur dengan tahu putih maka jumlah mikroorganisme tahu yang diberi perlakuan dengan Ekstrak bawang putih (Allium sativum L.) berbeda sangat nyata dengan tahu yang hanya diberi perlakuan kontrol.

Bawang putih (Allium sativum L.) merupakan bumbu dapur yang sangat populer. Aroma dan rasanya yang khas, dapat memberikan citarasa lezat dan harum pada masakan. Selain sebagai bumbu dapur, bawang putih ternyata sangat efektif sebagai pengawet. Hal ini disebabkan karena bawang putih dapat menghambat pertumbuhan khamir dan bakteri. Kandungan allicin di dalam bawang putih sangat efektif mematikan bakteri gram positif dan gram negatif. Bawang putih juga bersifat antimikroba E.coli, Shigella sonnei, Staphylococcus aureus dan Aerobacter aerogenes. Manfaat lainya adalah dapat mengurangi jumlah bakteri aerob,
E.coli dan mikroorganisme lainya sehingga bahan makanan yang ditambahkan bawang putih akan lebih awet. Sehingga dapat memberikan pengaruh daya awet tahu putih (Sutomo, 2012).

Berdasarkan Tabel 2 nilai rata-rata tingkat kesukaan terhadap aroma tahu putih menunjukkan nilai tertinggi 2,5125 dan 2,5 pada perlakuan $\mathrm{P}_{5}$ dan P3 dengan kriteri disukai. Kriteria agak disukai terdapat pada perlakuan $\mathrm{P}_{4}$ dan $\mathrm{P}_{1}$ dengan nilai 2,475 dan 2,4625 , sedangkan kriteria yang tidak disukai terdapat pada perlakuan $\mathrm{P}_{2}$ dan $\mathrm{P}_{0}$ dengan nilai 2,4125 dan 2,125.

Panelis banyak menyukai perlakuan $\mathrm{P}_{5}$ dan $\mathrm{P}_{3}$ karena makin lama penyimpanan aroma khas bawang putih semakin tercium sedangkan pada perlakuan $\mathrm{P}_{4}$ dan $\mathrm{P}_{1}$ aroma bawang putih hanya sedikit yang tercium, Kemudian pada perlakuan $\mathrm{P}_{2}$ dan $\mathrm{P}_{0}$ panelis memilih tidak menyukai dikarenakan hampir tidak beraroma bawang putih.

Berdasarkan Tabel 2 nilai rata-rata kesukaan panelis terhadap warna tahu putih menunjukkan nilai rata-rata tertinggi terhadap warna tahu putih yaitu pada perlakuan $\mathrm{P}_{1}$ dan $\mathrm{P}_{3}$ dengan nilai 3,0875 dan 3,0375 dengan kriteria sangat disukai karena tahu berwarna putih cerah, dan kriteria disukai terdapat pada perlakuan $\mathrm{P}_{2}$ dan $\mathrm{P}_{5}$ dengan nilai 2,6625 dan 2,5875, kemudian kriteria yang tidak disukai terdapat pada perlakuan $\mathrm{P}_{4}$ dengan nilai 2,3, sedangkan kriteria sangat tidak disukai terdapat pada perlakuan $\mathrm{P}_{0}$ dengan nilai 1,5125 dikarenakan tahu berwarna putih keruh.

Berdasarkan Tabel 2 nilai rata-rata kesukaan panelis terhadap tekstur tahu putih menunjukkan nilai rata-rata tertinggi terhadap tekstur tahu putih yaitu pada perlakuan $\mathrm{P}_{4}$ dan $\mathrm{P}_{5}$ dengan nilai 2,24583 dan 1,6625 dengan kriteria disukai dikarenakan tekstur tahu yang padat, dan kriteria agak disukai terdapat pada perlakuan $\mathrm{P}_{1}$ dan $\mathrm{P}_{2}$ dengan nilai 1,5875 dan 1,625 , sedangkan kriteria yang tidak disukai terdapat pada perlakuan $\mathrm{P}_{0}$ dan $\mathrm{P}_{3}$ dengan nilai 1,375 dan 1,525 karena tekstur tahu cenderung lembek.

\section{KESIMPULAN}

Berdasarkan hasil penelitian pada pengaruh lama penyimpanan terhadap daya awet tahu putih yang diberi ekstrak bawang putih (Allium sativum L.)yang telah dilaksanakan dapat disimpulkan bahwa:

1. Penambahan ekstrak bawang putih (Allium sativum L.) berpengaruh sangat nyata terhadap daya simpan dan daya awet tahu putih dilihat dari taraf signifikan pada Tabel $1 \mathrm{~F}$ hitung perlakuan lebih besar dari $\mathrm{F}$ tabel 0,05 dan $\mathrm{F}$ tabel 0,01 yaitu $2,93<43,306>4,58$. 
2. Untuk memperpanjang daya simpan dan daya awet tahu putih dapat digunakan ektrak bawang putih (Allium sativum L.) dengan kadar 80 gram yang di tambahkan kedalam tahu putih.

\section{DAFTAR PUSTAKA}

[1] Koswara, S. 2011. Catatan Kimia Formalin.Catatankimia.com

[2] Mariana, R. 2010. Studi Efektivitas Bahan Pengawet
PengawetanTahu.Skripsi. Institut Pertanian Bogor.

[3] Soeid, I. 2012. Pengawet Pengganti Formalin. Pustaka Pangan.com

[4] Sutomo, B. 2012 . Peran Bawang Putihsebagai Mikroba. Artikel Budi Sutomo mengenal-jenisfungsibumbu-rempah-nusantara-dankontinental) 